\title{
PERMASALAHAN PEMAHAMAN KONSEP SISWA PADA PELAJARAN MATEMATIKA KELAS 3 SEMESTER 1
}

\author{
Defi Prasasti ${ }^{1}$, Fitri Maulida Awalina ${ }^{2}$, Ulia Usawatun Hasana ${ }^{3}$ \\ Universitas Muhammadiyah Tangerang \\ defiprasasti14@gmail.com
}

\begin{abstract}
Mathematics education in elementary school is the beginning, starting from a child to explore bis ability to understand concepts in mathematics and his knowledge will greatly influence the level of further education. The subject of this research is grade 3 of SDN semester 1 consisting of 40 elementary students. The ability of students to understand and master mathematics is still relatively low when compared with other subjects, for example in mathematics. Students in solving the comparison questions, among others, misconceptions that is wrong in presenting the form of comparison, the principle mistakes made are wrong in using the principle of comparison comparison. Meanwhile, the operation error performed is in calculating the results of the comparison simplification. the factors causing student errors include a lack of student understanding of the material, inaccuracy in working on problems, as well as a lack of student interest in learning mathematics, so that it affects the learning outcomes of students. This must be the main concern of teachers in teaching mathematics, so students can be motivated to learn mathematics.
\end{abstract}

Keywords: Education, Mathematics, Schools

\begin{abstract}
Abstrak : Pendidikan matematika di sekolah dasar merupakan awal, mulai dari seorang anak untuk mendalami kemampuannya dalam memahami konsep-konsep di dalam matematika dan pengetahuanya yang didapat akan sangat mempengaruhi pada jenjang pendidikan selanjutnya. subjek penelitian ini adalah kelas 3 SDN semester 1 yang tediri dari 40 siswa sekolah dasar. Kemampuan siswa dalam memahami dan menguasai matematika masih relatif rendah jika di bandingkan dengan mata pelajaran lainya, contoh dalam pelajaran matematika. Peserta didik dalam menyelesaikan soal perbandingan, antara lain kesalahan konsep yaitu salah dalam menyajikan bentuk perbandingan, Kesalahan prinsip yang dilakukan yaitu salah dalam menggunakan prinsip penyerdahanaan perbandingan. Sedangkan, kesalahan operasi yang dilakukan yaitu dalam menghitung hasil penyerderhanaan perbandingan. faktor penyebab kesalahan siswa antara lain kurangnya pemahaman siswa terhadap materi, tidak teliti dalam mengerjakan soal, serta kurangnya minat siswa dalam belajar matematika, sehingga berpengaruh terhadap hasil belajar peserta didik. Hal inilah yang harus menjadi perhatian utama guru dalam mengajar matematika, sehingga peserta didik dapat termotivasi untuk belajar matematika.
\end{abstract}

Kata Kunci: Pendidikan, Matematika, Sekolah

Manazhim : Jurnal Manajemen dan Ilmu Pendidikan

Volume 2, Nomor 1, Februari 2020; 45-53

https://ejournal.stitpn.ac.id/index.php/manazhim 


\section{PENDAHULUAN}

Pendidikan memiliki peranan yang sangat penting dalam proses peningkatan kualitas sumber daya manusia. Oleh karena itu sudah sepatutnya pendidikan mendapat perhatian yang mendalam tentang nilai-nilai dan dasar-dasar untuk meningkatkan kualitas sumber daya manusia. Salah satu cara meningkatkan kualitas sumber daya manusia yakni dengan memperbaiki kualitas pembelajaran di sekolah.

Pendidikan matematika di sekolah dasar merupakan awal dari mulai seorang anak untuk mendalami kemampuannya dalam memahami konsep-konsep di dalam matematika dan pengetahuan yang didapat akan sangat mempengaruhinya pada jenjang pendidikan berikutnya. Hal ini sejalan dengan ${ }^{1}$ pendapat Hudojo (1990) bahwa matematika berhubungan dengan ide-ide/konsep-konsep abstrak yang tersusun secara hirarkis, untuk mempelajari suatu konsep yang berdasarkan pada konsep yang lain, seseorang perlu memahami lebih dahulu konsep prasyarat tersebut, tanpa memahami konsep prasyarat tersebut tidak mungkin orang itu memahami konsep barunya dengan baik. Untuk mendukung hal tersebut, materi matematika harus dikemas dan diolah sedemikan rupa menyenangkan dan dapat dimengerti oleh peserta didik.

Matematika merupakan salah satu mata pelajaran yang diberikan kepada semua peserta didik mulai dari sekolah dasar sampai perguruan tinggi untuk membekali peserta didik dengan kemampuan berpikir logis, analitis, sistematis, kritis, dan kreatif serta kemampuan bekerjasama Rahayu, 2008. Dengan demikian, diharapkan peserta didik dapat memenuhi tujuan dari pendidikan matematika yang ingin dicapai. Adapun tujuan dari pendidikan matematika Gravemeijer, 2007, ${ }^{2}$ yaitu: a. prasyarat untuk pendidikan selanjutnya; b. kebutuhan praktis dalam kehidupan sehari-hari; c. berfikir matematika; dan d. mengembangkan nilai-nilai kultur: pembelajaran yang demokrasi, keindahan matematika dan apresiasi peran matematika dalam masyarakat.

\footnotetext{
${ }^{1}$ Herman Hudojo, Strategi Mengajar Belajar Matematika. 1990 ( Malang : IKIP Malang ). Hlm.4.

2 Sari, Pramitha. Maret 2017. " Pemahaman Konsep Matematika Siswa Pada Materi Besar Sudut Melalui Pendekatan Pmri ".Jurnal Gantang Vol. II, No. 1
} 
Tujuan pembelajaran matematika di sekolah menurut Permendiknas No. 22 Depdiknas, 2006, ${ }^{3}$ hlm. 346 adalah: 1 . Memahami konsep matematika, menjelaskan keterkaitan antarkonsep dan mengaplikasikan konsep atau algoritma, secara luwes, akurat, efisien, dan tepat, dalam pemecahan masalah, 2. Menggunakan penalaran pada pola dan sifat, melakukan manipulasi matematika dalam membuat generalisasi, menyusun bukti, atau menjelaskan gagasan dan pernyataan matematika, 3. Memecahkan masalah yang meliputi kemampuan memahami masalah, merancang model matematika, menyelesaika $\mathrm{n}$ model dan menafsirkan solusi yang diperoleh, 4 . Mengomunikasikan gagasan dengan simbol, tabel, diagram, atau media lain untuk memperjelas keadaan atau masalah, dan 5. Memiliki sikap menghargai kegunaan matematika dalam kehidupan, yaitu memiliki rasa ingin tahu, perhatian, dan minat dalam mempelajari matematika, serta sikap ulet dan percaya diri dalam pemecahan masalah.

Sampai saat ini matematika masih dianggap sebagai mata pelajaran yang sulit dan tidak menyenangkan bagi siswa, sehingga banyak siswa yang kurang menyukai pelajaran matematika bahkanmatematika dianggap sebagai hal yang menakutkan. Padahal siswa yang kurang menyukai pelajaran matematika akan menyebabkan kecemasan yang membuat kesulitan dalam memahami materi yang disampaikan dan berdampak pada rendahnya prestasi belajar matematika. Hal tersebut didasarkan pada hasil data dari TIMSS, Trends in International Mathematics and Science Study pada tahun 2011 yang dilakukan setiap empat tahun sekali untuk mengetahui peningkatan pembelajaran matematika dan sains menunjukkan bahwa skor rata-rata prestasi matematika di Indonesia menempati peringkat 38 dari 42 negara.

Berdasarkan hasil PISA tahun 2009 menunjukkan bahwa hampir semua siswa Indonesia hanya menguasai pelajaran sampai level 3 saja, sementara negara lain banyak yang sampai level 4, 5, bahkan 6, Dewi, 20174. Demikian pula hasil kemampuan matematika melalui TIMSS tahun 2011 menunjukkan bahwa lebih dari 95\% siswa Indonesia hanya mampu sampai level menengah, sementara hampir 50\%

\footnotetext{
${ }^{3}$ Departemen Pendidikan Nasional. (2006). Permendiknas nomor 22 tabun 2006 tentang standar isi sekolah dasar. Jakarta: Depdiknas.

${ }^{4}$ I Md Suarjana, Desak Putu Parmiti, Pt Elma Arry Safitri. Februari 2018." Analisis Kesulitan Siswa Dalam Menyelesaikan Operasi Hitung Pecahan Siswa Sekolah Dasar ". Volume 2, Number 2, Tahun 2018, pp. 144-155
} 
siswa Taiwan mampu mencapai level tinggi dan advance Kemendikbud, dalam Dewi, 2017. Hal ini dapat memberikan gambaran mengenai tingkat pemahaman dan penguasaan siswa terhadap mata pelajaran matematika masih dalam taraf kemampuan berpikir tingkat rendah. Hal Ini membuktikan bahwa pemahaman konsep matematika siswa Indonesia masih sangat kurang

Pada kegiatan belajar mengajar guru sangat di butuhkan dalam mengatasi kesalahan peserta didik. Namun, sebelum guru mengetahui dimana latak kesulitan peserta didik dalam belajar matematika dan tidak memgetahui faktor penyebabnya, maka guru tidak dapat memberikan solusi atau tindakan dalam membantu peserta didiknya yang dalam belajar matematika beserta faktor penyebabnya. Masalah pada proses belajar mengajar siswa kelas 3 terbanyak pada materi perbandingan. Sehingga menyebabkan permasalahan pada Kesalahan konsep, Kesalahan prinsip, Kesalahan operasi.

\section{METODE}

Penelitian ini menggunakan jenis penelitian kualitatif. Dalam penelitian ini, peneliti menggunakan data deskriptif yang diperoleh dari pengumpulan data. Melalui observasi, dan wawancara. Dalam proses pelitian ini peneliti mencoba untuk dapatkan pemahaman yang lebih baik mengenai kompleksitas yang ada dalam interaksi manusia. Dengan metode kualitatif ini, penulis bisa mendapatkan data atau informasi yang lebih mendalam dan mendetail. Selain itu, pemilihan atas jenis penelitian kualitatif didasarkan atas alasan hendak memaknai sesuatu dan mencari keunikan tentang gaya belajar siswa.

Subjek dalam penelitian ini adalah narasumber atau partisipan, dan guru kelas 3. Guru kelas dijadikan subjek penelitian utama informan. Selain itu, guru kelas juga dipandang sebagai orang yang benar-benar mengetahui tentang narasumber. Dalam penelitian ini menggunakan teknik purposive sampling, yaitu teknik pengambilan sampel sumber data dengan pertimbangan tertentu, misalnya orang tersebut yang dianggap paling tahu tentang apa yang kita harapkan, atau mungkin dia sebagai penguasa sehingga akan memudahkan peneliti menjelajahi obyek/situasi sosial yang diteliti. 


\section{HASIL}

Sesuai dengan pemaparan pada pendahuluan, didapatkan bahwa kesalahan siswa terbanyak dilakukan pada materi perbandingan. Berikut ini adalah jenis-jenis kesalahan.

Tabel Rekapitulasi Jenis-jenis kesalahan.

\begin{tabular}{|c|c|c|c|c|}
\hline \multirow{2}{*}{ No } & \multirow{2}{*}{ Soal } & \multicolumn{3}{|c|}{ Jenis Kesalahan } \\
\hline & & $\begin{array}{l}\text { Kesalahan } \\
\text { konsep }\end{array}$ & Kesalahan prinsip & $\begin{array}{l}\text { Kesalahan } \\
\text { operasi }\end{array}$ \\
\hline 1 & $\begin{array}{l}\text { Jika umur kakak } 17 \\
\text { tahun,umur adek } 3 \\
\text { tahun, maka } \\
\text { perbandingan umur } \\
\text { kakak dan adik } \\
\text { adalah ..... }\end{array}$ & $\begin{array}{l}\text { Salah dalam } \\
\text { memyajikan } \\
\text { bentuk } \\
\text { perbandingan }\end{array}$ & $\begin{array}{l}\text { Salah dalam menggunkan } \\
\text { prinsip }\end{array}$ & $\begin{array}{l}\text { Salah dalam } \\
\text { perhitungan } \\
\text { hasil }\end{array}$ \\
\hline
\end{tabular}

Penelitian dilaksanakan di MI Yanida. Data diperoleh dengan menggunakan instrument wawancara terhadap peserta didik dan guru. observasi terhadap pembelajaran awal untuk mendeskripsikan pemahaman konsep matematika peserta didik yang berkaitan dengan perbandingan. Berdasarkan hasil wawancara yang dilaksanakan, peneliti menemukan permasalahan dalam pembelajaran matematika banyak peserta didik yang belum menguasai indikator pemahaman konsep. Sebagian peserta didik sudah mampu menyatakan ulang sebuah konsep, peserta didik masih kebingungan untuk mengenali objek berdasarkan sifatnya, peserta didik dengan bantuan guru mampu membedakan contoh dan bukan contoh, peserta didik kesulitan mengartikan soal terutama soal yang berbentuk cerita dan tidak mampu memodelkan pernyataan ke dalam bentuk matematika. Hal ini sejalan dengan pendapat Dharma, Suarjana dan Suartama (2016:3) yang menyatakan bahwa ternyata 
masih banyak terdapat siswa yang mengalami kesulitan dalam menyelesaikan soal matematika dalam bentuk cerita, memahami bahasa, apa yang ditanyakan dalam soal, dan dalam perhitungan.

\section{PEMBAHASAN}

Berdasarkan hasil wawancara, faktor-faktor tersebut terdapat pada faktor kesulitan siswa dalam menyelesaikan soal cerita pecahan yaitu berdasarkan hasil temuan siswa dikarenakan siswa tidak dapat menuliskan tahapan-tahapan penyelesaiannya dengan benar, serta penggunaan bahasa Indonesia yang kurang sehingga siswa sulit mengartikan dan menyelesaikan soal cerita yang diberikan. Temuan ini juga sejalan dengan hasil penelitian dari Suaryani, $2016{ }^{5}$ menyatakan bahwa "siswa mengalami kendala saat menyelesaikan soal cerita penggunaan bahasa Indonesia dalam pembelajaran jarang digunakan sehingga siswa sulit menyelesaikan soal cerita". Karena dalam keseharian siswa lebih banyak berkomunikasi menggunakan bahasa daerah yaitu bahasa Bali. Faktor kesulitan siswa saat menyelesaikan soal penjumlahan dan pengurangan pecahan berpenyebut tidak sama dikarenakan siswa masih merasa bingung saat karena ada konsep yang sering siswa lupakan yaitu konsep operasi hitung penjumlahan dan operasi hitung pengurangan. Siswa kesusahan dalam menyamakan penyebutnya terlebih dahulu karena harus mencari KPK. Faktor kesulitan siswa dalam mengerjakan soal menyederhanakan pecahan karena siswa tidak mengerti bagaimana cara menyederhanakan pecahan agar menjadi pecahan yang paling sederhana. Dalam menyederhanakan pecahan siswa malas dalam penyelesaian soal tersebut karena siswa harus mencari FPB.

Kesalahan siswa terbanyak dilakukan pada materi Perbandingan. Jenis-jenis kesalahan diklarafisikan diantaranya kesalahan konsep, kesalahan prinsip, kesalahan operasi . Contoh Jika umur kakak 17 tahun,umur adek 3 tahun, maka perbandingan umur kakak dan adik adalah .....

\footnotetext{
${ }^{5}$ Suaryani, Ni Wyn. 2016. “Analisis Kemampuan Siswa Dalam Menyelesaikan Operasi Hitung Pecahan Pada Siswa Kelas V”. E-Journal PGSD Universitas Pendidikan Ganesha, Volume 4, Nomor 1.
} 
Dari soal diatas,

\section{Kesalahan konsep}

Salah dalam menyajikan bentuk perbandingan.

Kesalahan ini terjadi karena peserta didik tidak teliti dalam mengerjakan soal dan tidak memahami soal atau konsep pemecahan yang di gunakan dalam perbandingan dengan baik.

2. Kesalahan prinsip

\section{Salah dalam menggunakan prinsip}

Kesalahan terjadi ketika peserta didik membagi kedua bilangan dengan angka yang sama untuk membagi kedua bilangan dengan angka yang sama untuk membagi kedua bilangan tersebut. Hal ini, dikarenakan karena siswa belum mengerti dan memahami materi yang diajarkan .

3. kesalahan Operasi

\section{Salah dalam menghitung hasil penyerderhanaan perbandingan}

Kesalahan dilakukan peserta didik ketika tidak teliti dalam melakukan operasi hitung pembagian. Peserta didik tidak terbiasa melakukan operasi hitung perkalian dan pembagian. Hal ini akan mempengaruhi kecepatan berhitungnya dan berpengaruh terhadap studynya pada tingkat lebih lanjut. Dari hasil wawancara dengan guru dan beberapa siswa faktor-faktor kesulitan siswa dalam menyelesaikan operasi hitung pecahan diperoleh faktor kesulitan siswa dalam menyelesaikan soal cerita pecahan siswa mengalami kesulitan saat menyelesaikan soal cerita pecahan karena kurangnya penggunaan bahasa Indonesia dalam pembelajaran serta siswa tidak mengetahui tahapan-tahapan dalam menyelesaikan soal cerita dengan benar. Kemudian siswa mengalami kesulitan saat menyelesaikan soal penjumlahan dan pengurangan pecahan berpenyebut tidak sama karena ada konsep yang sering siswa lupakan yaitu konsep operasi hitung penjumlahan dan operasi hitung pengurangan serta siswa tidak mengerti bagaimana cara menyamakan penyebut dan siswa kurang memperhatikan guru saat menjelaskan materi. Siswa tidak bisa dalam menyederhanakan pecahan karena siswa tidak mengerti bagaimana cara menyederhanakan pecahan agar menjadi pecahan yang paling sederhana. 
Adapun solusi yang dapat diberikan untuk megatasi kesulitan siswa dalam menyelesaikan operasi hitung pecahan sesuai dengan hasil wawancara dengan guru dan beberapa siswa yaitu untuk mningkatkan pengetahuan awal dan pemahaman konsep siswa sebaiknya cara mengajar guru lebih ditingkatkan lagi misalnya guru dalam menjelaskan materi pecahan dapat menjelaskan secara perlahan sehingga siswa tidak merasa penjelasan yang diberikan oleh guru terlalu cepat dan siswa dapat memahami konsep pecahan dengan baik kemudian guru bisa mengemas pembelajaran agar lebih bervariasi lagi. Metode yang digunakan dalam pembelajaran sebaiknya lebih bervariasi. Penggunaan media dan alat peraga juga sangat diperlukan. Sebaiknya penggunaan bahasa Indonesia hendaknya lebih sering digunakan dalam pembelajaran agar siswa terbiasa menggunaan bahasa tersebut sehingga saat diberikan soal cerita siswa dapat mudah memahami maksud dari soal tersebut. Solusi yang dapat diberikan juga melalui peran oragtua atau keluarga dalam memimbing anak di rumah.

\section{KESIMPULAN}

Berdasarkan hasil analisis yang telah dipaparkan, dapat disimpulkan bahwa peserta didik dalam menyelesaikan soal perbandingan, antara lain kesalahan konsep yaitu salah dalam menyajikan bentuk perbandingan. Kesalahan prinsip yang dilakukan yaitu salah dalam menggunakan prinsip penyerdahanaan perbandingan. Sedangkan kesalahan operasi yang dilakukan yaitu dalam menghitung hasil penyerderhanaan perbandingan.

Dalam penelitian ini, faktor yang mempengaruhi kesalahan peserta didik dalam mengerjakan soal matematika antara lain kurangnya pemahaman peserta didik terhadap materi, tidak teliti dalam mengerjakan soal, serta kurangnya minat peserta didik dalam belajara matematika. Solusi yang dirasa tepat untuk mengatasi hal ini yaitu dengan menyesuaikan model dam metode pembelajaran dalam materi pembelajaran. Pada mata pelajaran matematika, model pembelajaran kontekstual akan lebih terlatih dan lebih teliti dalam mengerjakan soal matematika. Menumbuhkan minta belajar peserta didik dapat dilakukan dengan menjadikan matematika menjadi 
pelajaran yang menyenangkan dengan memberikan games dan menggunakan strategi yang sesuai dengan materi dan perserta.

\section{DAFTAR PUSAKA}

Aksha, M., dan shaleh.2017 peningkatan perserta didik dalam memahami konsep penjumlahan pecahan.lentera, 1(2):9-1

Ali hamzah,dkk.2014.perencanaan dan strategi pembelajaran matematika.jakarta

Departemen Pendidikan Nasional. (2006). Permendiknas nomor 22 tahun 2006 tentang standar isi sekolah dasar. Jakarta: Depdiknas.

Hudoyo, H (1990). Strategi Belajar Mengajar Matematika. Malang : IKIP Malang

Hudojo, Herman. 2001. Pengembangan Kurikulum dan Pembelajaran Matematika. Jurusan Pendidikan Matematika. Universitas Negeri Malang.

I Md Suarjana, Desak Putu Parmiti, Pt Elma Arry Safitri. Februari 2018.” Analisis Kesulitan Siswa Dalam Menyelesaikan Operasi Hitung Pecahan Siswa Sekolah Dasar". Volume 2, Number 2, Tahun 2018, pp. 144-155

Japa, I Gusti Ngurah dan I Made Suarjana. 2015. Pendidikan Matematika I. Singaraja: Universitas Pendidikan Ganesha.

Lexy j moleong. 1991. Metode penelitian kualitatif.bandung

Masihtoh. 2019.Peningkatan pemahaman konsep matematika dan kemampuan berpikir kritis matematika siswa kelas $V$ sekolah dasr melalui pembelajaran eksploratif.

Santoso,Yulia Pratiwi. 2017. Analisis kesalahan siswa kelas III SDN MONJOSARI dalam Meyelesaikan Soal Perbandingan Pecahan. Siduarjo

Sari , Pramita . 2017. Pemahaman Konsep Matematika siswa pada materi besar sudut melalui pendekatan PMRI. Palembang.

Suaryani, Ni Wyn. 2016. "Analisis Kemampuan Siswa Dalam Menyelesaikan Operasi Hitung Pecahan Pada Siswa Kelas V'. E-Journal PGSD Universitas Pendidikan Ganesha, Volume 4, Nomor 1.

Wulandari putri dwi.2019.meningkatkan pemahaman konsep matematika siswa sd melalui spembelajaran dengan pendekatan problem posing. 